\title{
Epigenetic Changes in Equine Embryos after Short-Term Storage at Different Temperatures
}

\author{
Gustavo D. A. Gastal ${ }^{1,2, *(\mathbb{D})}$, Dragos Scarlet ${ }^{3}$, Maria Melchert ${ }^{1}$, Reinhard Ertl ${ }^{4} \oplus$ and Christine Aurich ${ }^{1, *(1)}$ \\ 1 Center for Artificial Insemination and Embryo Transfer, Department for Small Animals and Horses, \\ University of Veterinary Medicine Vienna, 1210 Vienna, Austria; Maria.Melchert@vetmeduni.ac.at \\ 2 Instituto Nacional de Investigación Agropecuaria INIA, Estación Experimental La Estanzuela, Ruta 50 km 11, \\ 39173 Colonia, Uruguay \\ 3 Division of Obstetrics, Gynecology and Andrology, Department for Small Animals and Horses, University of \\ Veterinary Medicine Vienna, 1210 Vienna, Austria; dragos.scarlet@uzh.ch \\ 4 Vetcore Facility, University of Veterinary Medicine Vienna, 1210 Vienna, Austria; \\ Reinhard.Ertl@vetmeduni.ac.at \\ * Correspondence: ggastal@inia.org.uy (G.D.A.G.); christine.aurich@vetmeduni.ac.at (C.A.)
}

check for updates

Citation: Gastal, G.D.A.; Scarlet, D.; Melchert, M.; Ertl, R.; Aurich, C. Epigenetic Changes in Equine Embryos after Short-Term Storage at Different Temperatures. Animals 2021, 11, 1325. https://doi.org/10.3390/ ani11051325

Academic Editor: Chris W. Rogers

Received: 16 March 2021

Accepted: 3 May 2021

Published: 6 May 2021

Publisher's Note: MDPI stays neutral with regard to jurisdictional claims in published maps and institutional affiliations.

Copyright: (c) 2021 by the authors. Licensee MDPI, Basel, Switzerland. This article is an open access article distributed under the terms and conditions of the Creative Commons Attribution (CC BY) license (https:// creativecommons.org/licenses/by/ $4.0 /)$.
Simple Summary: In embryos subjected to assisted reproductive techniques, epigenetic modifications may occur that can influence embryonic development and establishment of pregnancy. In horses, the storage temperature during transport of fresh embryos before transfer is a major concern. The aim of this study was, therefore, to determine the effects of two storage temperatures $\left(5^{\circ} \mathrm{C}\right.$ and $20^{\circ} \mathrm{C}$ ) on equine embryos, collected at day seven after ovulation and stored for $24 \mathrm{~h}$, concerning morphological development, expression of candidate genes associated with embryo growth and development, maternal recognition of pregnancy, methylation, apoptosis and gene-specific and global DNA methylation. Temperature during storage did not affect embryo size. There were no changes in $\mathrm{pH}$ and lipid peroxidation of the medium irrespective of group. mRNA expression and gene-specific DNA methylation of genes related to growth and development, maternal recognition of pregnancy, DNA methylation and apoptosis in stored embryos $\left(5^{\circ} \mathrm{C}\right.$ and $\left.20^{\circ} \mathrm{C}\right)$ were altered when compared to fresh embryos. Therefore, our study demonstrates for the first time the gene-specific and global DNA methylation status of fresh equine embryos collected on days seven and eight after ovulation. Short-term storage, regardless of temperature, may compromise embryo development after transfer.

Abstract: In embryos subjected to assisted reproductive techniques, epigenetic modifications may occur that can influence embryonic development and the establishment of pregnancy. In horses, the storage temperature during transport of fresh embryos before transfer is a major concern. The aim of this study was, therefore, to determine the effects of two storage temperatures $\left(5^{\circ} \mathrm{C}\right.$ and $\left.20^{\circ} \mathrm{C}\right)$ on equine embryos, collected at day seven after ovulation and stored for $24 \mathrm{~h}$, on: (i) morphological development; (ii) expression of candidate genes associated with embryo growth and development, maternal recognition of pregnancy, methylation and apoptosis, and (iii) gene-specific and global DNA methylation. Embryos $(n=80)$ were collected on day seven or day eight after ovulation and assigned to four groups: day seven control (E7F, fresh); day seven, stored for $24 \mathrm{~h}$ at $5{ }^{\circ} \mathrm{C}(\mathrm{E} 5 \mathrm{C})$; day seven, stored for $24 \mathrm{~h}$ at $20^{\circ} \mathrm{C}$ (E20C) and day eight control (E8F, fresh $24 \mathrm{~h}$ time control). The embryos and the storage medium (EquiHold, holding medium, Minitube, Tiefenbach, Germany) from all treatment groups were analyzed for (i) medium temperature, $\mathrm{pH}$, and lipid peroxidation (malondialdehyde; MDA) and (ii) embryo morphology, mRNA expression and DNA methylation (immunohistochemistry and gene-specific DNA methylation). The size of embryos stored at $5{ }^{\circ} \mathrm{C}$ was larger $(p<0.01)$, whereas embryos stored at $20{ }^{\circ} \mathrm{C}$ were smaller $(p<0.05)$ after $24 \mathrm{~h}$. There were no changes in $\mathrm{pH}$ and MDA accumulation irrespective of the group. The mRNA expression of specific genes related to growth and development (POU5F1, SOX2, NANOG), maternal recognition of pregnancy (CYP19A1, PTGES2), DNA methylation (DNMT1, DNMT3A, DNMT3B) and apoptosis $(B A X)$ in the E5C and E20C were either up or downregulated $(p<0.05)$ when compared to controls (E7F and E8F). The immune expression of $5 \mathrm{mC}$ and $5 \mathrm{hmC}$ was similar among treatment groups. 
Percentage of methylation in the CpG islands was lower in the specific genes ESR1, NANOG and DNMT1 $(p<0.001)$ in E20C embryos when compared to E8F (advanced embryo stage). Therefore, our study demonstrates for the first time the gene-specific and global DNA methylation status of fresh equine embryos collected on days seven and eight after ovulation. Although our results suggest some beneficial effects of storage at $20^{\circ} \mathrm{C}$ in comparison to $5{ }^{\circ} \mathrm{C}$, the short-term storage, regardless of temperature, modified gene expression and methylation of genes involved in embryo development and may compromise embryo viability and development after transfer.

Keywords: equine; embryo; transport; methylation; development; embryo-maternal recognition

\section{Introduction}

Assisted reproduction techniques (ART) in horses have considerably advanced during the last decade. In this field, artificial insemination along with embryo transfer are still the most common ART applied to horses [1]. The production of embryos by ovum pickup and subsequent intracytoplasmic sperm injection, however, is attracting increasing attention. Because of a limited availability of recipient mares at facilities that collect fresh embryos, or produce in vitro embryos, the shipment of such embryos is required with increasing frequency. Similarly, techniques that require specific laboratory equipment, such as cryopreservation, or require preimplantation genetic diagnosis, often demand overnight transport and sometimes transport back thereafter [2,3]. Equine embryos are transferred at day seven or eight after ovulation [1,4], with the majority developed to the blastocyst stage at the time of transfer [5]. For overnight transport, embryos are either cooled to $5{ }^{\circ} \mathrm{C}$ or kept at room temperature [6]. Therefore, transportation is a critical issue that can contribute to success or failure of subsequent embryo transfer.

During the development of preimplantation embryos, a wave of epigenetic reprogramming takes place to establish the totipotent state [7]. Epigenetics refer to certain hereditary DNA or chromosome alterations, such as methylation, histone modification and genome imprinting [8,9]. The reprogramming of DNA methylation is a necessary step for subsequent embryo development [10]. Processes involved in ART have been associated with epigenetic reprogramming disturbances [11], increasing the incidence of pregnancy complications [12] and imprinting disorders such as Beckwith-Wiedemann Syndrome (BWS), Angelman syndrome and retinoblastoma in children conceived with the help of ART [13]. In cattle, large offspring syndrome was described in calves derived from ART, which has been associated with loss of methylation and downregulation of certain maternally-expressed genes [14]. Embryo exposure to environments other than the uterus can alter cell metabolism [15] due to different types of environmental stress (e.g., temperature or exposure to chemicals; [16]), and the related oxidative stress can contribute to abnormal DNA methylation leading to impairment of embryonic development and failure in maternal recognition of pregnancy [16-18].

During early embryonic development, an increased expression of growth factors leads to proliferation of trophectoderm cells and prostaglandin production, likely involved in maternal recognition of pregnancy [19]. At the same time, DNA methyltransferases (DNMTs) play an important role in maintaining genome stability and integrity during development and epigenetic reprogramming [20], with DNMT1, DNMT3A, DNMT3B, and $D N M T 3 L$ being the main genes involved in the establishment of methylation patterns required for cell lineage determination [21-23]. There is evidence that DNA methylation occurs mainly at the cytosines of cytosine-guanine dinucleotides (CpG) known as CpG sites [20]. Interactions between DNA and gene regulatory proteins can be critically influenced by the dynamics of DNA methylation. Genomic 5-methyl-2'-deoxycytidine (5mC) is recognized by methyl-DNA binding proteins that recruit histone deacetylases and can be reduced via oxidation to 5-hydroxymethyl-2'-deoxycytidine (5hmC) [24]. Therefore, 
changes in $5 \mathrm{mC}$ and $5 \mathrm{hmC}$ reflect global DNA methylation and hydroxymethylation in tissues and cells.

Whereas extensive information is available on epigenetic changes in oocytes and conceptuses derived from ART in humans, mice and cattle [24-27], information with respect to horses is scarce $[28,29]$. Our study followed the hypothesis that storage temperature contributes to epigenetic changes in equine embryos. To test our hypothesis, we evaluated if storage temperature of equine embryos alters the epigenetic reprogramming causing effects on gene expression of candidate genes associated with maternal recognition of pregnancy, embryo development, methylation and apoptosis involved in genetic reprogramming. Embryos collected on day seven after ovulation were either stored at $5{ }^{\circ} \mathrm{C}$ or $20^{\circ} \mathrm{C}$ for $24 \mathrm{~h}$. Fresh embryos collected on day seven or eight served as untreated controls. The following parameters were determined: (i) morphological development; (ii) gene expression of candidate genes associated with maternal recognition of pregnancy, embryo development, methylation and apoptosis, and (iii) gene-specific and global DNA methylation.

\section{Materials and Methods}

\subsection{Animals and Reproductive Management}

All experimental procedures were performed according to Austrian animal welfare legislation and approved by the Austrian Federal Ministry for Science and Research (license number BMWFW-68.205/0135-WF/V /3b / 2014). Fifteen healthy and fertile Haflinger mares (4-16 years old) were used as embryo donors. Animals were kept in a large paddock with access to a shed, fed with hay and mineral supplements twice daily, and water was available ad libitum. The ovaries and uterus of mares were scanned transrectally with an ultrasound machine (Mindray M9, Mindray, Shenzhen, China) equipped with 5-8 MHz linear-array transducer (6LE5Vs) to detect a $3.5 \mathrm{~cm}$ preovulatory follicle and uterine oedema characterizing estrous, and to determine the time for artificial insemination [30]. Insemination was performed with extended (Equi Pro, Minitube, Tiefenbach, Germany) semen. One insemination dose contained at least 500 million progressively motile spermatozoa. Semen was collected from fertile stallions by artificial vagina using routine procedures [31]. The mares were inseminated at intervals of $48 \mathrm{~h}$ and checked every $24 \mathrm{~h}$ until ovulation was detected. No hormonal treatments were administered during the experimental period.

\subsection{Experimental Design}

Equine embryos $(n=80)$ were collected on day seven $(n=60)$ or day eight $(n=20)$ after ovulation and assigned to four groups with 20 embryos per group: (i) day seven control (E7F, fresh); (ii) day seven, $24 \mathrm{~h}$ at $5{ }^{\circ} \mathrm{C}$ (E5C); (iii) day seven, $24 \mathrm{~h}$ at $20{ }^{\circ} \mathrm{C}$ (E20C); (iv) day eight control (E8F). For short-term storage, embryos were kept in holding medium (EquiHold, Minitube) within an Equitainer (Hamilton Biovet, Ipswich, MA, USA), with or without freezer cans (E5C and E20C, respectively). The embryos and medium from all treatments were submitted to the following assessments: temperature, $\mathrm{pH}$, lipid peroxidation, embryo morphology, mRNA expression and DNA methylation (immunohistochemistry and gene-specific DNA methylation).

\subsection{Collection and Evaluation of Embryos}

Embryos were recovered on days seven and eight after ovulation (day 0, ovulation detection) using an intrauterine silicone two-way Foley catheter $\mathrm{CH} 28$ for mares (Minitube). The uterus was flushed four times with $1 \mathrm{~L}$ of Ringer's lactate solution (Fresenius Kabi, Graz, Austria) prewarmed at $38^{\circ} \mathrm{C}$. The fluid recovered from the uterus was filtered through an embryo filter system $(75 \mu \mathrm{m}$, EmCon embryo filter; Immunosystems, Spring Valley, WI, USA). The solution remaining in the filter cup was placed in a petri dish and analyzed under a stereomicroscope at $40 \times$ magnification. Embryos were washed 10 times in holding medium (Minitube) to remove cellular debris. Embryos were measured before and immediately after the storage period under stereo microscope with an eyepiece 
micrometer, and morphologically classified according to their stage of development and quality on a scale from 1 (excellent) to 4 (degenerated) as described [32].

\subsection{Holding Medium Temperature and $p H$}

The temperature of the holding medium was recorded with a data logger (testo 175, Testo, West Chester, PA, USA) every $10 \mathrm{~min}$ for $24 \mathrm{~h}$. Briefly, a second tube with the same volume of holding medium as for the embryo was placed inside the Equitainer, and the fine sensor of the data logger was placed inside this holding medium for temperature monitoring. The $\mathrm{pH}$ was assessed in a sample of the holding medium immediately before and after embryo storage for $24 \mathrm{~h}$. The $\mathrm{pH}$ was assessed by a $\mathrm{pH}$ meter (SevenCompact S220-micro-kit, Mettler Toledo, Columbus, OH, USA) using the microelectrode (InLab Ultra-Micro-ISM, Mettler Toledo, Columbus, OH, USA) for small sample volumes.

\subsection{Lipid Peroxidation}

Lipid peroxidation was determined by the reaction of malondialdehyde (MDA) with thiobarbituric acid (TBA) to form a fluorometric $(\lambda \mathrm{ex}=532 / \lambda \mathrm{em}=553 \mathrm{~nm})$ product, proportional to the MDA present, using a commercial kit (Cat\#MAK085, Sigma-Aldrich Co., St. Louis, MO, USA) and following the principles and methods previously described [33]. Briefly, the MDA standards were prepared by dilution of $10 \mu \mathrm{L}$ of the $4.17 \mathrm{M}$ MDA standard solution with $407 \mu \mathrm{L}$ of water to prepare a $0.1 \mathrm{M}$ MDA standard solution. Further, $20 \mu \mathrm{L}$ of the $0.1 \mathrm{M}$ MDA standard solution was diluted with $980 \mu \mathrm{L}$ of water to prepare a $2 \mathrm{mM}$ MDA standard to generate 0 (blank), $0.4,0.8,1.2,1.6$, and 2.0 nanomole standards. Later, a sample $(20 \mu \mathrm{L})$ of the spent holding medium was gently mixed with $500 \mu \mathrm{L}$ of $42 \mathrm{mM}$ sulfuric acid in a microcentrifuge tube. Phosphotungstic acid solution $(125 \mu \mathrm{L})$ was added to the samples, mixed by vortex, incubated at room temperature for $5 \mathrm{~min}$, and then centrifuged at $13,000 \times g$ for $3 \mathrm{~min}$. The pellet was resuspended on ice with the $100 \mu \mathrm{L}$ water/BHT solution ( $2 \%$ ) and adjusted to a volume of $200 \mu \mathrm{L}$ with water. The assay reaction was performed following the manufacturer instructions using a fluorometer (Victor 2D, Perkin Elmer, Santa Clara, CA, USA) and the data were analyzed by the software SoftMax Pro 6.5.1. (Molecular Devices, LLC, Sunnyvale, CA, USA). All samples and standards were run in duplicate.

\subsection{Quantitative Real-Time PCR}

Embryos from all groups ( $n=24,6$ per group) were placed in $350 \mu \mathrm{L}$ RLT buffer (Qiagen, Hilden, Germany) and stored at $-80^{\circ} \mathrm{C}$. For RNA extraction from single embryos, 3.5 $\mu \mathrm{L}$ 2-mercapoethanol (Sigma-Aldrich, St. Louis, MO, USA) were added to the solution and RNA extraction and DNase I digestion were performed with the RNeasy Micro Kit (Qiagen, Hilden, Germany) according to the recommended protocol for animal and human tissues. For qPCR, $6 \mu \mathrm{L}$ of total RNA were transcribed into cDNA using the SuperScript III First-Strand Synthesis system with random hexamer primers (Invitrogen, Carlsbad, CA, USA) in accordance with the manufacturer's instructions. Primer and hydrolysis probes for the equine target genes ATP1A1, BAX, BCL2, CYP19A1, DNMT1, DNMT3A, DNMT3B, DNMT3L, ESR1, H19, IGF1, IGF2, NANOG, POU5F1, PTGES2 and SOX2 were designed using the PrimerQuest assay tool (https:// eu.idtdna.com/PrimerQuest/Home/ Index; accessed on 6 May 2021; Integrated DNA Technologies, Coralville, IA, USA) or taken from the literature [34-37]. Two reference genes (RG), PSMB4 and SNRPD3, were included for normalization [38]. Assay details and full names of the genes investigated are listed in Table 1. All hydrolysis probes were dual-labelled with 6-carboxyfluorescein (FAM) on the $5^{\prime}$ end and Black Hole Quencher 1 (BHQ1) on the $3^{\prime}$ end. The assays were validated by generation of standard curves to determine PCR reaction efficiencies using the formula $E=10^{-1 / \text { slope }}-1$ [39]. Efficiency-corrected $C_{q}$ values were used for analysis. Real-time PCR quantification of the target genes using hydrolysis probes was performed as described [37]. The RGs were measured with the fluorescent DNA dye SYBR Green. Reaction conditions were described previously [38]. Target gene expression levels were 
normalized to the geometric mean of PSMB4 and SNRPD3, and relative expression changes were calculated with the comparative $2^{-\Delta \Delta C T}$ method [40].

Table 1. Primer for quantitative PCR.

\begin{tabular}{|c|c|c|c|c|c|c|c|}
\hline $\begin{array}{c}\text { Gene } \\
\text { Symbol }\end{array}$ & Gene Name & $\begin{array}{l}\text { NCBI/Ensembl } \\
\text { Accession } \\
\text { Number }\end{array}$ & Oligo Sequence $\left(5^{\prime}-3^{\prime}\right)$ & $\begin{array}{l}\text { Amplicon } \\
\text { Length (bp) }\end{array}$ & $\begin{array}{l}\text { PCR Ef- } \\
\text { ficiency } \\
\text { (\%) }\end{array}$ & $\begin{array}{c}\mathbf{R}^{2} \\
\text { Value }\end{array}$ & Reference \\
\hline ATP1A1 & $\begin{array}{l}\text { Equus caballus } \\
\text { ATPase } \mathrm{Na}+/ \mathrm{K}+ \\
\text { transporting } \\
\text { subunit alpha } 1\end{array}$ & $\begin{array}{l}\text { NM_001114532.2, } \\
\text { XM_023640223.1, } \\
\text { XM_023640224.1 }\end{array}$ & $\begin{array}{c}\text { F: CTTGAT- } \\
\text { GAACTTCAGCG- } \\
\text { CAAATA } \\
\text { R: GGTG- } \\
\text { TAAGGGCATTGGGA }\end{array}$ & 104 & 94 & 0.990 & This study \\
\hline BAX & $\begin{array}{l}\text { Equus caballus } \\
\text { BCL2-associated X } \\
\text { protein }\end{array}$ & $\begin{array}{l}\text { XM_014729721.1 } \\
\text { XM_014729717.1 }\end{array}$ & $\begin{array}{c}\text { P: TGAGCCGAGGCT- } \\
\text { TAACAACTGCTC } \\
\text { F: AGGATGCGTC- } \\
\text { CACCAAGAAG } \\
\text { R: CCTCTGCAGCTC- } \\
\text { CATGTTACTG } \\
\text { P: } \\
\text { CTCAAGCGCATCG- }\end{array}$ & 80 & 93.2 & 0.994 & [37] \\
\hline BCL2 & $\begin{array}{c}\text { Equus caballus } \\
\text { B-cell lymphoma } 2\end{array}$ & XM_001490436.2 & $\begin{array}{c}\text { GAGATGAGCTG } \\
\text { F: TTGGAAAGCCTAC- } \\
\text { CACTAATTGC } \\
\text { R: CCGTGTTATAG- } \\
\text { GCACAGGAGAT } \\
\text { P: CCCACCTGAGCG- }\end{array}$ & 74 & 92.6 & 0.998 & [37] \\
\hline CYP19A1 & $\begin{array}{l}\text { Equus caballus } \\
\text { cytochrome P450 } \\
\text { family } 19 \\
\text { subfamily A } \\
\text { member } 1\end{array}$ & $\begin{array}{l}\text { NM_001081805.2 } \\
\text { XM_005602588.2 } \\
\text { XM_005602587.2 }\end{array}$ & $\begin{array}{c}\text { F: GGAGAG- } \\
\text { GAAACGCTCGT- } \\
\text { TATTA } \\
\text { R: CCCATATACTG- } \\
\text { CAACCCAAATG } \\
\text { P: ATCACTACTCCTC- } \\
\text { CCGATTTGGCA }\end{array}$ & 107 & 99.2 & 0.999 & This study \\
\hline DNMT1 & $\begin{array}{c}\text { Equus caballus } \\
\text { DNA } \\
\text { methyltransferase 1 }\end{array}$ & XM_014741825.1 & $\begin{array}{c}\text { F: GACCACCAT- } \\
\text { CACGTCTCATTT } \\
\text { R: CTCCTCATCCACA- } \\
\text { GAATTGTCC } \\
\text { P: AAACGGAAACCC- } \\
\text { GAGGAAGAGCTG }\end{array}$ & 97 & 100.5 & 1 & This study \\
\hline \multirow[t]{2}{*}{ DNMT3A } & \multirow{2}{*}{$\begin{array}{l}\text { Equus caballus } \\
\text { DNA } \\
\text { methyltransferase } \\
3 \alpha\end{array}$} & $\begin{array}{l}\text { XM_005600169.2 } \\
\text { XM_005600168.2 } \\
\text { XM_005600167.2 }\end{array}$ & $\begin{array}{l}\text { F: GATTATTGAC- } \\
\text { GAACGCACAAGAG }\end{array}$ & 112 & 100 & 0.998 & This study \\
\hline & & $\begin{array}{l}\text { XM_005600170.2 } \\
\text { XM_005600171.2 }\end{array}$ & $\begin{array}{l}\text { R: GTGTTCCAGGGT- } \\
\text { GACATTGA } \\
\text { P: TGCAAATGTCTTC- } \\
\text { GATGTTCCGGC }\end{array}$ & & & & \\
\hline DNMT3B & $\begin{array}{c}\text { Equus caballus } \\
\text { DNA } \\
\text { methyltransferase } \\
3 \beta\end{array}$ & XM_001916514.4 & $\begin{array}{c}\text { F: CGAGTCTTGTCC- } \\
\text { CTGTTTGAT } \\
\text { R: GCGATA- } \\
\text { GACTCTTCACA- } \\
\text { CACTT }\end{array}$ & 110 & 100.6 & 0.999 & This study \\
\hline DNMT3L & $\begin{array}{l}\text { Equus caballus } \\
\text { DNA (cytosine-5-)- } \\
\text { methyltransferase } \\
\text { 3-like }\end{array}$ & XM_014736476.1 & $\begin{array}{c}\text { P: CGC- } \\
\text { CACAGGGTACTTG- } \\
\text { GTTCTCAA } \\
\text { F: GCCCTCACTTG- } \\
\text { GTTGGTTT } \\
\text { R: CTTCCA- } \\
\text { CACAGGCACAGTTT } \\
\text { P: } \\
\text { CAAAGTGCCCATCT- } \\
\text { GCTCTGGAGA }\end{array}$ & 98 & 100.5 & 0.999 & This study \\
\hline
\end{tabular}


Table 1. Cont.

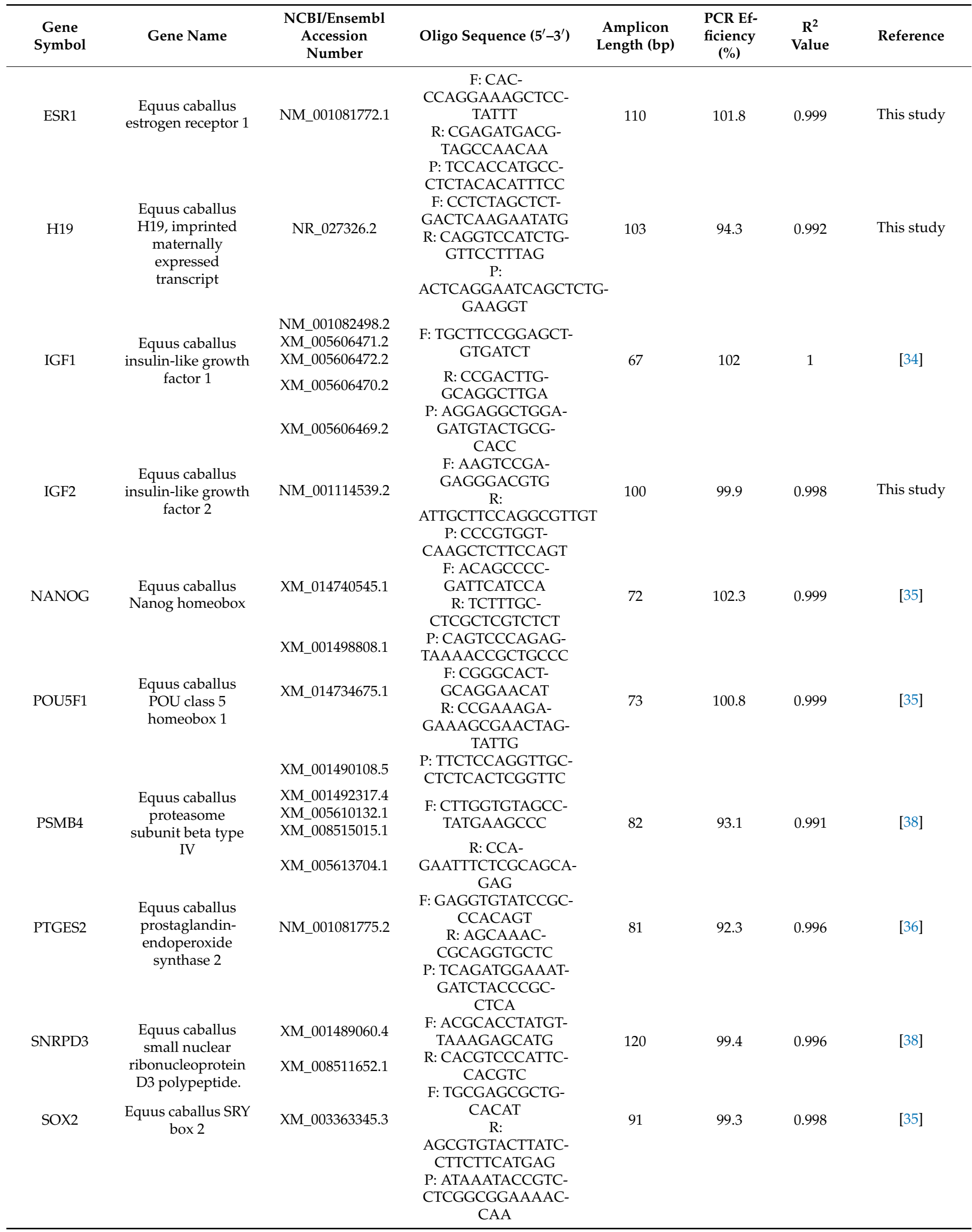

$\mathrm{R}^{2}$ : correlation coefficient of standard curve; F and R: forward and reverse primer; P: hydrolysis probe. 


\subsection{Gene-Specific DNA Methylation Analysis}

The analysis of gene-specific DNA methylation was based on a protocol previously implemented for bovine oocytes [41]. Briefly, DNA from single equine embryos $(n=28$; $n=7$ per group) was isolated and bisulfite-treated with the EZ DNA Methylation Direct Kit (Zymo Research, Irvine, CA, USA) following the recommended protocol for samples containing up to $2 \times 10^{3}$ cells. Bisulfite-converted DNA was eluted with $10 \mu \mathrm{L}$ M-Elution Buffer (Zymo Research, Irvine, CA, USA) into $1.5 \mathrm{~mL}$ DNA LoBind tubes (Eppendorf, Hamburg, Germany). Selection of target regions for bisulfite sequencing and primer design was done with the MethPrimer online tool [42]. The genomic sequences 2,000 bp upstream of the transcription start sites of the equine genes, CYP19A1, DNMT1, DNMT3A, DNMT3B, ESR1, NANOG, PTGES2 and SOX2 were screened for CpG islands or CG-rich regions using the $\mathrm{CpG}$ island prediction function of the MethPrimer tool. For multiplex nested PCR, two sets of primers, an outer primer for a first-round multiplex PCR amplification of all eight genes and an inner primer for a second gene-specific single nested PCR were designed for each gene (Table 2). Primers were designed to bind outside the CG-rich areas and to amplify as many $\mathrm{CpG}$ dinucleotides as possible. Only one primer set could be designed for PTGES2, which was used in both PCR reactions. The multiplex PCR was performed in $25 \mu \mathrm{L}$ reaction volumes including $200 \mu \mathrm{M}$ of each dNTP, $1 \times$ buffer B2 (Solis BioDyne, Tartu, Estonia), $3 \mathrm{mM} \mathrm{MgCl}, 120 \mathrm{nM}$ of each outer primer, 1.2 units HOT FIREPol DNA polymerase (Solis BioDyne, Tartu, Estonia) and $2 \mu \mathrm{L}$ bisufite-treated DNA. The PCR reaction was carried out using the following temperatures: initial denaturation at $95^{\circ} \mathrm{C}$ for $10 \mathrm{~min}$, followed by 34 cycles of $95^{\circ} \mathrm{C}$ for $30 \mathrm{sec}, 54^{\circ} \mathrm{C}$ for $30 \mathrm{sec}$, and $72{ }^{\circ} \mathrm{C}$ for $1 \mathrm{~min}$, and a final elongation step at $72{ }^{\circ} \mathrm{C}$ for $7 \mathrm{~min}$. One $\mu \mathrm{L}$ of the multiplex PCR product was used as the template for the subsequent nested PCR performed in $25-\mu \mathrm{L}$ reaction volumes using the same mastermix components as described for the multiplex PCR, except that the outer primer-mix was replaced with $500 \mathrm{nM}$ of each gene-specific inner forward and reverse primer. The temperature protocol for multiplex PCR was also applied for the nested PCR, except that the annealing temperature and cycle number were adjusted for each gene $\left(C Y P 19 A 1: 56^{\circ} \mathrm{C}, 35\right.$ cycles; DNMT1 and DNMT3A: $59{ }^{\circ} \mathrm{C}, 35$ cycles; DNMT3B, ESR1 and NANOG: $60^{\circ} \mathrm{C}, 35$ cycles; PTGES2: $56{ }^{\circ} \mathrm{C}, 40$ cycles; SOX2: $58{ }^{\circ} \mathrm{C}, 40$ cycles). Aliquots of the PCR products were run in a $2 \%$ agarose gel to confirm the correct size of the amplicons. The remaining aliquots were used for direct Sanger sequencing performed by Microsynth, Vienna, Austria. To improve the quality of the sequencing data, the amplicons of ESR1 and PTGES2 were isolated from the $2 \%$ agarose gel and purified using the Zymoclean Gel DNA Recovery kit (Zymo Research, Irvine, CA, USA) prior to sequencing. Data analysis was performed with CLC Genomics Workbench 9 software (Qiagen). The sequence electropherograms were investigated for methylated " $\mathrm{C}$ " and unmethylated " $\mathrm{T}$ " peaks within a $\mathrm{CpG}$ context. CpGs with a " $\mathrm{C}$ " signal $>80 \%$ were categorized as methylated, whereas methylation values $<20 \%$ were categorized as unmethylated. Methylation values between 20 and $80 \%$ were designated as an unclear methylation status [41].

\subsection{Global Methylation-Immunofluorescence Staining for $5 \mathrm{mC}$ and $5 \mathrm{hmC}$}

Embryos ( $n=28 ; n=7$ per group) from all treatment groups were prepared for immunofluorescence staining as previously described [43,44], with minor modifications. Briefly, embryos were removed from the holding medium, washed in PBS and fixed in ice-cold 4\% paraformaldehyde (PFA; Sigma-Aldrich, St. Louis, MO, USA) for 25 min at room temperature (RT). Embryos were washed in PBS and kept for 25 min at RT in PBT (0.05\% Tween-20 in PBS), permeabilized in $0.2 \%$ triton X-100 solution for $40 \mathrm{~min}$ at RT, washed three times and stored in $100 \mu \mathrm{L}$ of PBT at $4{ }^{\circ} \mathrm{C}$ for the antibody staining. Embryos were depurinated in $4 \mathrm{~N} \mathrm{HCl} 0.1 \%$ Triton X-100 for $20 \mathrm{~min}$ at RT, washed in PBS and kept in PBT for $30 \mathrm{~min}$ at RT and incubated in blocking solution (2\% BSA in PBT) overnight at $4{ }^{\circ} \mathrm{C}$. Later, embryos were incubated with the primary antibody $(5 \mathrm{mC}$ mouse monoclonal antibody, EpiGentek, Farmingdale, NY, USA; or 5hmC mouse monoclonal antibody, Active 
Motif, Carlsbad, Ca, USA) at 1:200 in blocking solution for 1h at RT, washed in PBT and incubated with Alexa Fluor 594 goat antimouse IgG (Thermo, Waltham, MA, USA) for $1 \mathrm{~h}$ in blocking solution at RT in the dark. Finally, embryos were washed in PBT, incubated in DAPI solution for $10 \mathrm{~min}$ at RT, then washed in PBT and prepared in a chamber for confocal microscopy (LSM 880, Carl Zeiss, Oberkochen, Germany). Scanning was conducted with Z stack of 25 optical series from the bottom to the top of the embryos with a step size of $65 \mu \mathrm{m}$ to allow three-dimensional distribution analysis. Images were obtained at $20 \times$ objective magnification and analyzed using ImageJ software (version 1.50f). The fluorescence values from the embryos were recorded as integrated densities in arbitrary units (au). The following formula was used to analyze the correct relative fluorescence intensity (FI) for $5 \mathrm{mC}$ and $5 \mathrm{hmC}: \mathrm{FI}=$ (integrated density of $5 \mathrm{mC}$ or $5 \mathrm{hmC} /$ integrated density of DAPI).

Table 2. Multiplex nested PCR primer for DNA methylation analysis.

\begin{tabular}{|c|c|c|c|c|c|}
\hline Gene & Primer Sequence $\left(5^{\prime}-3^{\prime}\right)$ & $\begin{array}{l}\text { Amplicon } \\
\text { Length (bp) }\end{array}$ & $\begin{array}{c}\text { Genomic } \\
\text { Localization } \\
\text { (EquCab3.0) }\end{array}$ & $\begin{array}{l}\text { Number of } \\
\text { CpGs in Inner } \\
\text { Amplicon }\end{array}$ & $\begin{array}{l}\text { Number of } \\
\text { Sequenced } \\
\text { CpGs }\end{array}$ \\
\hline \multirow[t]{2}{*}{ CYP19A1 } & $\begin{array}{c}\text { Outer forward: } \\
\text { TTTTAGTTTTGATTGGTTGTTTTT } \\
\text { Outer reverse: CTAAACCC- } \\
\text { CATAAAACATCTCTTAC }\end{array}$ & 317 & $\begin{array}{c}\text { 1:140151317- } \\
140151633\end{array}$ & - & - \\
\hline & $\begin{array}{c}\text { Inner forward: TTTTTTTTGTAA- } \\
\text { GATTAGTGAGTATATTTA } \\
\text { Inner reverse: TTTCCAAAAT- } \\
\text { TAAAAAACATAACC }\end{array}$ & 212 & $\begin{array}{c}\text { 1:140151386- } \\
140151597\end{array}$ & 4 & 3 \\
\hline \multirow[t]{2}{*}{ DNMT1 } & $\begin{array}{c}\text { Outer forward: AATTTTTTTTAA- } \\
\text { GAGTTTGGTATGG } \\
\text { Outer reverse: ACCAATCCTC- } \\
\text { CTCTTTATACTAAAA }\end{array}$ & 264 & $\begin{array}{c}\text { 7:51536766- } \\
51537029\end{array}$ & - & - \\
\hline & $\begin{array}{c}\text { Inner forward: GAGTTTGGTATG- } \\
\text { GTATATAAGTGTTGA } \\
\text { Inner reverse: AAAAAACTAACC- } \\
\text { CTAAACTCACATC }\end{array}$ & 229 & $\begin{array}{c}7: 51536778- \\
51537006\end{array}$ & 9 & 8 \\
\hline \multirow[t]{2}{*}{ DNMT3A } & $\begin{array}{c}\text { Outer forward: GGGATTGATTA- } \\
\text { GATTTTTTAGAGAAG } \\
\text { Outer reverse: TAATAACAC- }\end{array}$ & 316 & $\begin{array}{c}15: 71656615- \\
71656930\end{array}$ & - & - \\
\hline & $\begin{array}{c}\text { TAAATCCCTCCAAAAC } \\
\text { Inner forward: TAGGAGTT- } \\
\text { TAGTGGGGGAATAGT } \\
\text { Inner Reverse: } \\
\text { ATAAAATAAATAAAACCCCTA- } \\
\text { CACC }\end{array}$ & 200 & $\begin{array}{c}15: 71656665- \\
71656864\end{array}$ & 6 & 4 \\
\hline \multirow[t]{2}{*}{ DNMT3B } & $\begin{array}{c}\text { Outer forward: } \\
\text { TTAAAGGGGGAATAGTA- } \\
\text { GAAGTTTA } \\
\text { Outer reverse: CAACTC- } \\
\text { CAAAAATATTTAAAATCAC }\end{array}$ & 388 & $\begin{array}{c}22: 24214245- \\
24214632\end{array}$ & - & - \\
\hline & $\begin{array}{c}\text { Inner forward: TATAGAGGATG- } \\
\text { GATTTGGGATTTTA } \\
\text { Inner reverse: ACTAAACACTCCC- } \\
\text { TACCCTAATACC }\end{array}$ & 240 & $\begin{array}{c}22: 24214309- \\
24214548\end{array}$ & 10 & 8 \\
\hline \multirow[t]{2}{*}{ ESR1 } & $\begin{array}{c}\text { Outer forward: TTGTGGTAGGTAT- } \\
\text { GAATATTTATGTG } \\
\text { Outer reverse: ATTACATATA- }\end{array}$ & 334 & $\begin{array}{c}31: 15363114- \\
15363447\end{array}$ & - & - \\
\hline & $\begin{array}{c}\text { CAACCAACCACAAAC } \\
\text { Inner forward: AATTTT- } \\
\text { TAGTGGGAGGAAGTATAGTAT } \\
\text { Inner reverse: ACATAAACTAA- } \\
\text { CAAAAAACATCCC }\end{array}$ & 226 & $\begin{array}{c}31: 15363156- \\
15363381\end{array}$ & 9 & 8 \\
\hline
\end{tabular}


Table 2. Cont.

\begin{tabular}{|c|c|c|c|c|c|}
\hline Gene & Primer Sequence $\left(5^{\prime}-3^{\prime}\right)$ & $\begin{array}{l}\text { Amplicon } \\
\text { Length (bp) }\end{array}$ & $\begin{array}{c}\text { Genomic } \\
\text { Localization } \\
(\text { EquCab3.0) }\end{array}$ & $\begin{array}{l}\text { Number of } \\
\text { CpGs in Inner } \\
\text { Amplicon }\end{array}$ & $\begin{array}{c}\text { Number of } \\
\text { Sequenced } \\
\text { CpGs }\end{array}$ \\
\hline \multirow[t]{2}{*}{ NANOG } & $\begin{array}{l}\text { Outer forward: TGGAAATATGGT- } \\
\text { GAATTTATAGGTAT } \\
\text { Outer reverse: AACTTAAATATC- }\end{array}$ & 387 & $\begin{array}{c}6: 36542573- \\
36542959\end{array}$ & - & - \\
\hline & $\begin{array}{l}\text { Inner forward: TTGGTAGATAG- } \\
\text { GATTAATTGAGAATT } \\
\text { Inner reverse: CAAACAAAAAAC- } \\
\text { CTTAAAAAAATAC }\end{array}$ & 237 & $\begin{array}{c}6: 36542585- \\
36542821\end{array}$ & 8 & 7 \\
\hline PTGES2 & $\begin{array}{c}\text { Forward: GATTTATTTAA- } \\
\text { GAGTGGGGGAGGT } \\
\text { Reverse: } \\
\text { CAATATAAAACCCCAACC }\end{array}$ & 205 & $\begin{array}{c}25: 32059289- \\
32059493\end{array}$ & 17 & 11 \\
\hline \multirow[t]{2}{*}{ SOX2 } & $\begin{array}{c}\text { Outer forward: ATTTTTAATATA- } \\
\text { GAATAAATTATGGAGAAG } \\
\text { Outer reverse: } \\
\text { AAATAAAAATAAAACAAAA- }\end{array}$ & 302 & $\begin{array}{c}19: 22733114- \\
22733417\end{array}$ & - & - \\
\hline & $\begin{array}{c}\text { CAAAATAAATA } \\
\text { Inner forward: ATAGAATAAAT- } \\
\text { TATGGAGAAGTAAGGAG } \\
\text { Inner reverse: CTATCCTAC- } \\
\text { TAAAATTTCAAAAACC }\end{array}$ & 253 & $\begin{array}{c}19: 22733122- \\
22733376\end{array}$ & 19 & 13 \\
\hline
\end{tabular}

\subsection{Statistical Analysis}

The software SPSS version 24 (IBM-SPSS, Armonck, NY, USA) was used for statistical analyses. Data were tested for normal distribution by Kolmogorov-Smirnov test. Because embryo size was not normally distributed $(p<0.05)$, comparison of embryo size among groups was made with nonparametrical tests (Mann-Whitney test for fresh embryos collected on days seven and eight, Wilcoxon test for the comparison of embryo size before and after storage in groups E5C and E20C, respectively). For the analysis of $\mathrm{pH}$, lipid peroxidation, gene expression, and DNA methylation, one-way ANOVA with subsequent Tukey test were used to analyze differences among groups. Spearman's rank correlation was calculated to evaluate the relationships among the genes. Data are shown as mean \pm standard error of the mean (SEM). A $p$-value $<0.05$ was considered statistically significant.

\section{Results}

\subsection{Recovery Rate and Embryo Morphology}

A total of 80 embryos were obtained from 144 embryo flushing procedures; therefore, the overall recovery rate was 55\% (80/144). Of the embryos collected, $92 \%$ were at the blastocyst and $8 \%$ at the morula stage. All embryos had a morphological classification of 1 or 2. Embryo size differed $(p<0.05)$ between fresh embryos collected on day seven $(\mathrm{E} 7 \mathrm{~F} ; n=20)$ and day eight $(\mathrm{E} 8 \mathrm{~F} ; n=16$; Figure 1$)$. The size of embryos stored at $5{ }^{\circ} \mathrm{C}$ $(\mathrm{E} 5 \mathrm{C} ; n=20)$ was larger $(p<0.01)$, whereas in embryos stored at $20{ }^{\circ} \mathrm{C}(\mathrm{E} 20 \mathrm{C} ; n=19)$ the size was smaller $(p<0.05)$ after $24 \mathrm{~h}$. In five embryos (one of E20C and four of E8F), data from size determination were not available. In the E5C group, there was an increase in size in 17 and a decrease in three embryos, whereas in the E20C group, there was in increase in size in four, a decrease in 12 and no change in size in three embryos $(p=0.02)$. No significant difference in size among embryos collected on day seven was detected. Fresh embryos collected on day eight were larger $(p<0.01)$ than embryos stored for $24 \mathrm{~h}$, irrespective of storage temperature. In 10 embryos (six in E20C and four in E5C) of the storage groups, a shrinkage-like morphology was detected irrespective of temperature (Figure 2). For the determination of gene expression and gene-specific DNA methylation, 
only blastocysts of similar development stage and $\geq 300 \mu \mathrm{m}$ in diameter at collection (in total $n=52$ ) were used.

(a) Fresh embryos

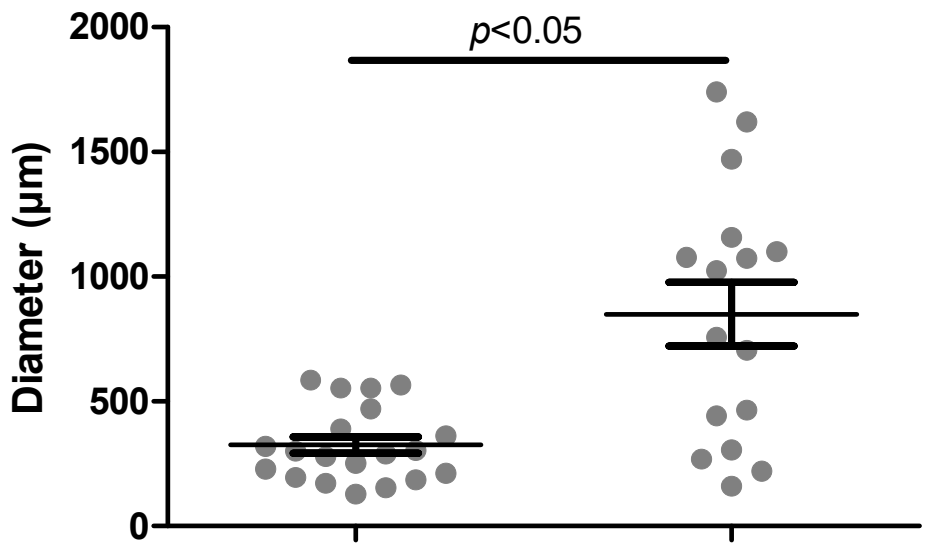

(b) Embryos stored at $5^{\circ} \mathrm{C}$

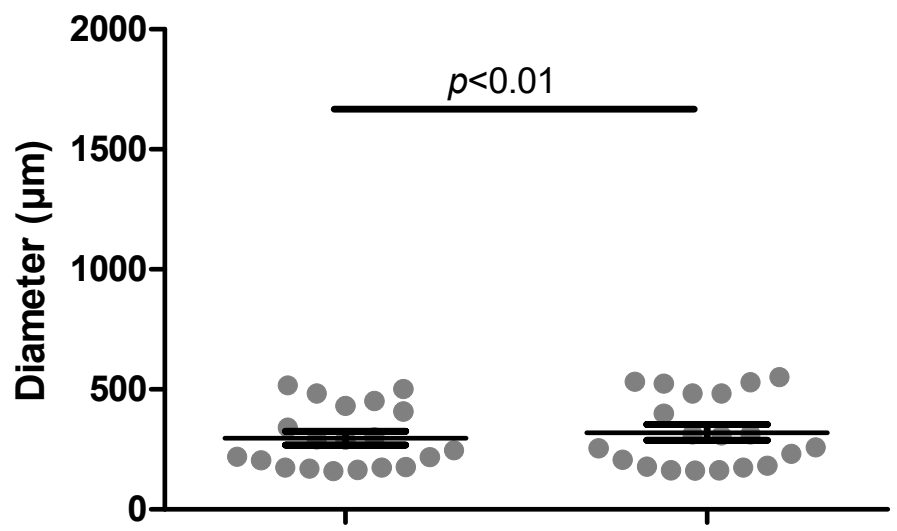

(c) Embryos stored at $20^{\circ} \mathrm{C}$

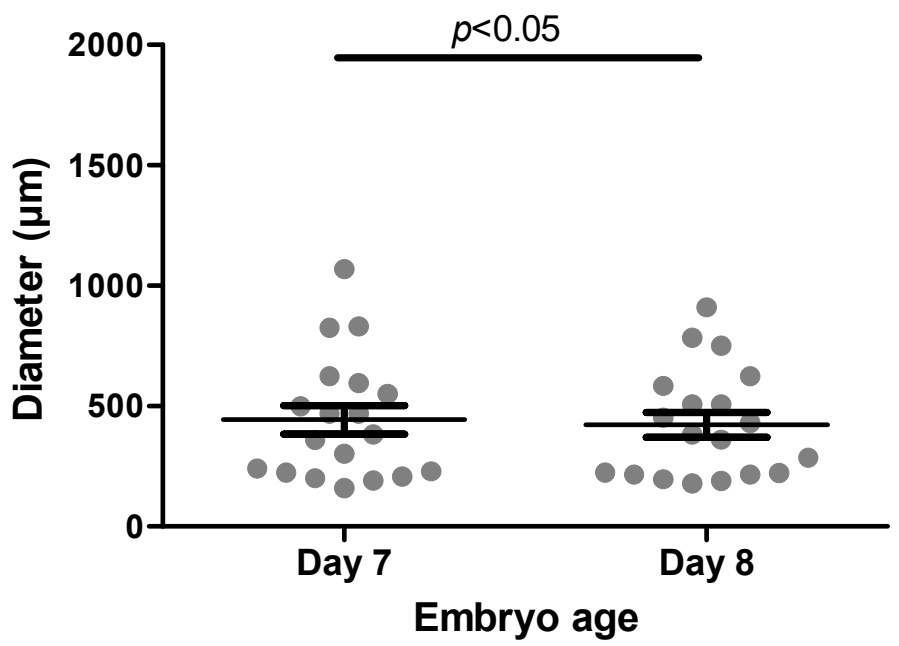

Figure 1. Diameter of fresh embryos. (a) collected on day seven (E7F) and day eight (E8F) after ovulation, and before (d7) and after $24 \mathrm{~h}(\mathrm{~d} 8)$ short-term storage at (b) $5{ }^{\circ} \mathrm{C}(\mathrm{E} 5 \mathrm{C})$ and $(\mathbf{c}) 20^{\circ} \mathrm{C}(\mathrm{E} 20 \mathrm{C})$. Each dot represents a single embryo. The plot represents the descriptive variation (mean \pm S.E.M.) within the group. Significant differences are indicated in the figure. 


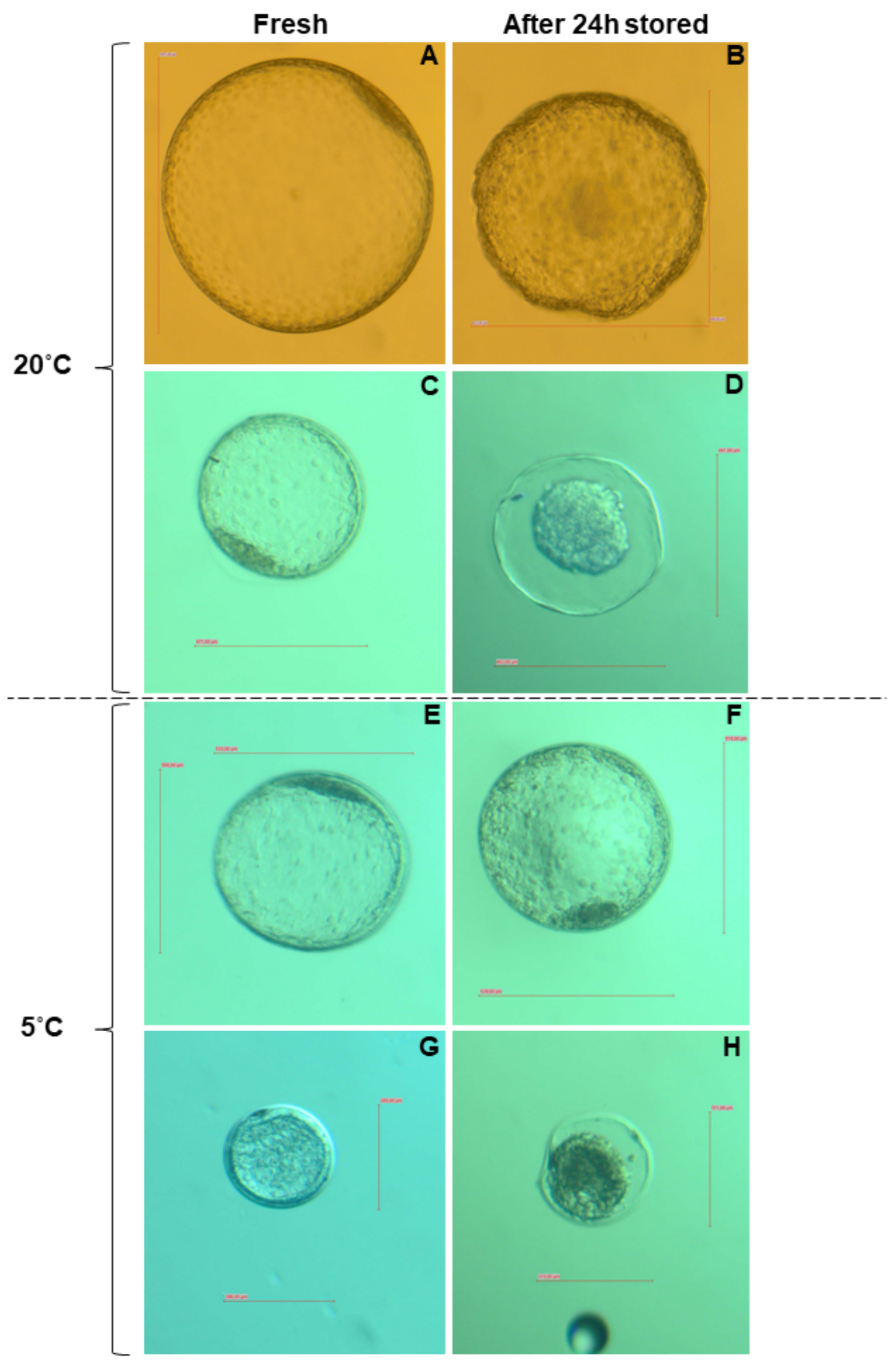

Figure 2. Illustration of fresh equine embryos (E7F) and stored in either $20{ }^{\circ} \mathrm{C}$ or $5{ }^{\circ} \mathrm{C}$ for $24 \mathrm{~h}$. $(\mathrm{A}, \mathrm{C}, \mathrm{E}, \mathrm{G})$ Embryos at blastocyst stage with normal morphology before submission to storage and $(\mathbf{B}, \mathbf{D}, \mathbf{F}, \mathbf{H})$ the same embryos after storage with (B) embryo with a slight shrinkage of the embryonic cells and few areas of detachment between the trophoblast cells, zona pellucida and embryonic capsule; (F) embryo with normal morphology after storage time; $(\mathbf{D}, \mathbf{H})$ embryos with strong shrinkage morphology of the embryonic cells. 


\subsection{Medium Temperature, $p H$, and Lipid Peroxidation}

The temperature of the storage medium was constant for all embryos within the temperature groups during the storage period. The $\mathrm{pH}$ of the medium $(7.22 \pm 0.07$ and $7.22 \pm 0.09$ ) was similar in groups E5C and E20C. In the spent holding medium, MDA accumulation could not be detected irrespective of treatment group.

\subsection{Gene Expression}

The relative mRNA abundance of specific genes related to growth and development, embryo-maternal communication, methylation and apoptosis is depicted in Figure 3. The gene DNMTL3L was not expressed in equine embryos irrespective of group. The expression of IGF1, POU5F1, SOX2, NANOG, CYP19A1, PTGS2, DNMT1, DNMT3a, DNMT3b, and $B A X$ differed among groups $(p<0.05)$. Gene expression of IGF1, CYP19A1 was similar in the two groups of stored embryos irrespective of temperature and control embryos collected on day seven, but higher in embryos collected on day eight. A different pattern with regard to mRNA abundance was determined for SOX2, NANOG, PTGES2, DNMT1 and DNMT3b. On the one hand, the gene expression was similar in day seven control embryos and embryos stored at $5{ }^{\circ} \mathrm{C}$ and, on the other hand, day eight controls and embryos stored at $20^{\circ} \mathrm{C}$. Gene expression of POU5F1 differed in E5C embryos in comparison to E20C and E8F groups. The expression of DNMT3a of E5C differed from all the other groups. BAX expression was lower in fresh embryos collected on day eight only when compared to stored embryos at $5{ }^{\circ} \mathrm{C}$. Independently of the treatment groups, we observed variations in the coexpression among the specific genes related to growth and development, embryo-maternal recognition, methylation and apoptosis (Table 3).

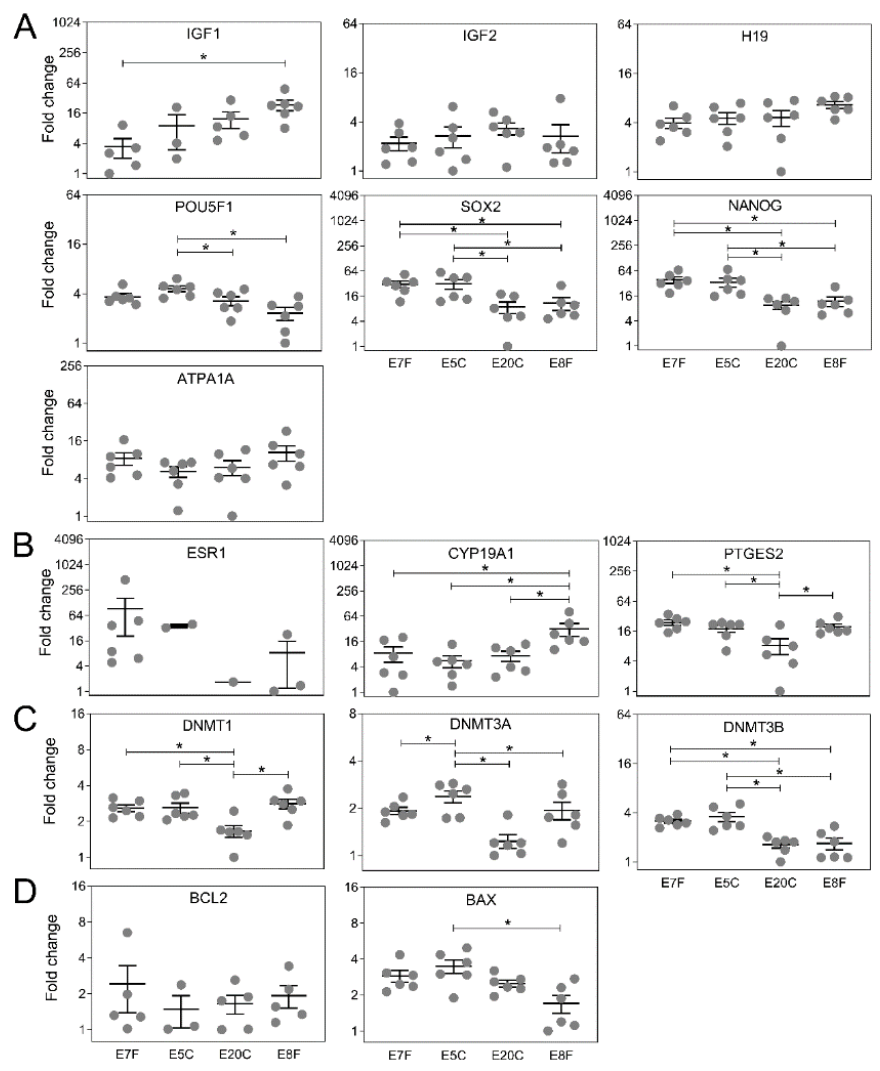

Figure 3. Relative mRNA expression levels of genes related to: (A) growth and development, (B) embryo-maternal communication, (C) methylation, and (D) apoptosis in fresh control (E7F and E8F) and stored embryos (E5C and E20C). E5C and E20C either did not express ESR1 or did not have enough samples; therefore, values were not considered for statistical comparison. Each dot represents a single embryo. The plot represents the descriptive variation (mean \pm S.E.M., $n=6$ ) within the group. Fold-changes were calculated with the comparative $2^{-\Delta \Delta \mathrm{CT}}$ method $\left({ }^{*} p<0.05\right)$. 
Table 3. Spearman rank correlation coefficient (Spearman's rho) among the specific genes in equine embryos.

\begin{tabular}{|c|c|c|c|c|c|c|c|c|c|c|c|c|c|c|c|c|}
\hline \multicolumn{2}{|c|}{ Function } & \multicolumn{7}{|c|}{$\begin{array}{c}\text { Growth \& } \\
\text { Development }\end{array}$} & \multicolumn{3}{|c|}{$\begin{array}{c}\text { Embryo-Maternal } \\
\text { Communication }\end{array}$} & \multicolumn{3}{|c|}{ Methylation } & \multicolumn{2}{|c|}{ Apoptosis } \\
\hline & Gene & IGF2- & H19 & POU5F1 & SOX2 & IGF1 & NANOG & ATPA1A & ESR1 & CYP19A1 & PTGES2 & DNMT1 & DNMT3a & DNMT3b & BCL2 & BAX \\
\hline \multirow{5}{*}{$\begin{array}{c}\text { Growth \& } \\
\text { Development }\end{array}$} & IGF2 & 1 & & & & & & & & & & & & & & \\
\hline & POU5F1 & 0.26 & -0.05 & 1 & & & & & & & & & & & & \\
\hline & SOX2 & 0.21 & -0.14 & $0.74^{* * *}$ & 1 & & & & & & & & & & & \\
\hline & IGF1 & -0.06 & 0.34 & $0.74^{* * *}$ & $-0.66^{* *}$ & 1 & & & & & & & & & & \\
\hline & NANOG & 0.07 & -0.27 & $0.73^{* * *}$ & $0.89 * * *$ & $-0.63^{* *}$ & 1 & & & & & & & & & \\
\hline \multirow{3}{*}{$\begin{array}{c}\text { Embryo- } \\
\text { maternal } \\
\text { communication }\end{array}$} & ESR1 & 0.04 & -0.05 & 0.33 & 0.45 & -0.43 & 0.2 & 0.18 & 1 & & & & & & & \\
\hline & CYP19A1 & -0.24 & $0.4^{*}$ & $-0.74^{* * *}$ & $-0.59 * *$ & 0.49 * & -0.51 * & $0.5^{*}$ & -0.12 & 1 & & & & & & \\
\hline & PTGES2 & 0.14 & 0.16 & -0.1 & 0.14 & 0.03 & 0.26 & 0.37 & 0.15 & 0.1 & 1 & & & & & \\
\hline \multirow{3}{*}{ Methylation } & DNMT1 & -0.23 & 0.29 & -0.11 & 0.1 & 0.49 * & 0.19 & $0.45^{*}$ & 0.27 & $0.47^{*}$ & $0.7^{* * *}$ & 1 & & & & \\
\hline & DNMT3a & -0.12 & 0.19 & 0.32 & 0.5 & 0.02 & $0.58^{* *}$ & 0.14 & 0.54 & -0.04 & 0.45 * & $0.65^{* * *}$ & 1 & & & \\
\hline & DNMT3b & -0.04 & -0.05 & $0.75^{* * *}$ & $0.82 * * *$ & $-0.59^{* *}$ & $0.91^{* * *}$ & -0.36 & 0.29 & -0.39 & 0.3 & 0.29 & $0.57^{* *}$ & 1 & & \\
\hline \multirow{2}{*}{ Apoptosis } & BCL2 & -0.04 & 0.24 & 0.21 & 0.05 & 0.01 & 0.14 & 0.03 & 0.38 & 0.09 & -0.07 & 0.23 & 0.43 & 0.07 & 1 & \\
\hline & BAX & 0.07 & -0.22 & $0.77^{* * *}$ & $0.55^{* *}$ & $-0.69^{* *}$ & $0.58^{* *}$ & $-0.6^{* *}$ & 0.34 & $-0.54^{* *}$ & -0.04 & -0.12 & 0.05 & $0.67^{* * *}$ & -0.02 & 1 \\
\hline
\end{tabular}

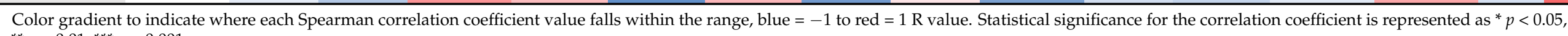
${ }^{* *} p<0.01,{ }^{* * *} p<0.001$. 


\subsection{Gene-Specific DNA Methylation}

The percentage of overall DNA methylation and the overview of DNA methylation results of single CpGs of the specific genes are depicted in Table 4 and Figure 4, respectively. The predicted promoter region of CYP19A1 was fully methylated whereas PTGES2 and SOX2 were unmethylated in all embryos irrespective of treatment group. For DNMT1, the methylation status was similar in the two groups of fresh embryos and embryos stored at $5{ }^{\circ} \mathrm{C}$, whereas it was lower in embryos stored at $20^{\circ} \mathrm{C}$. The methylation status of NANOG, however, was higher in fresh day eight embryos than in the other three groups.

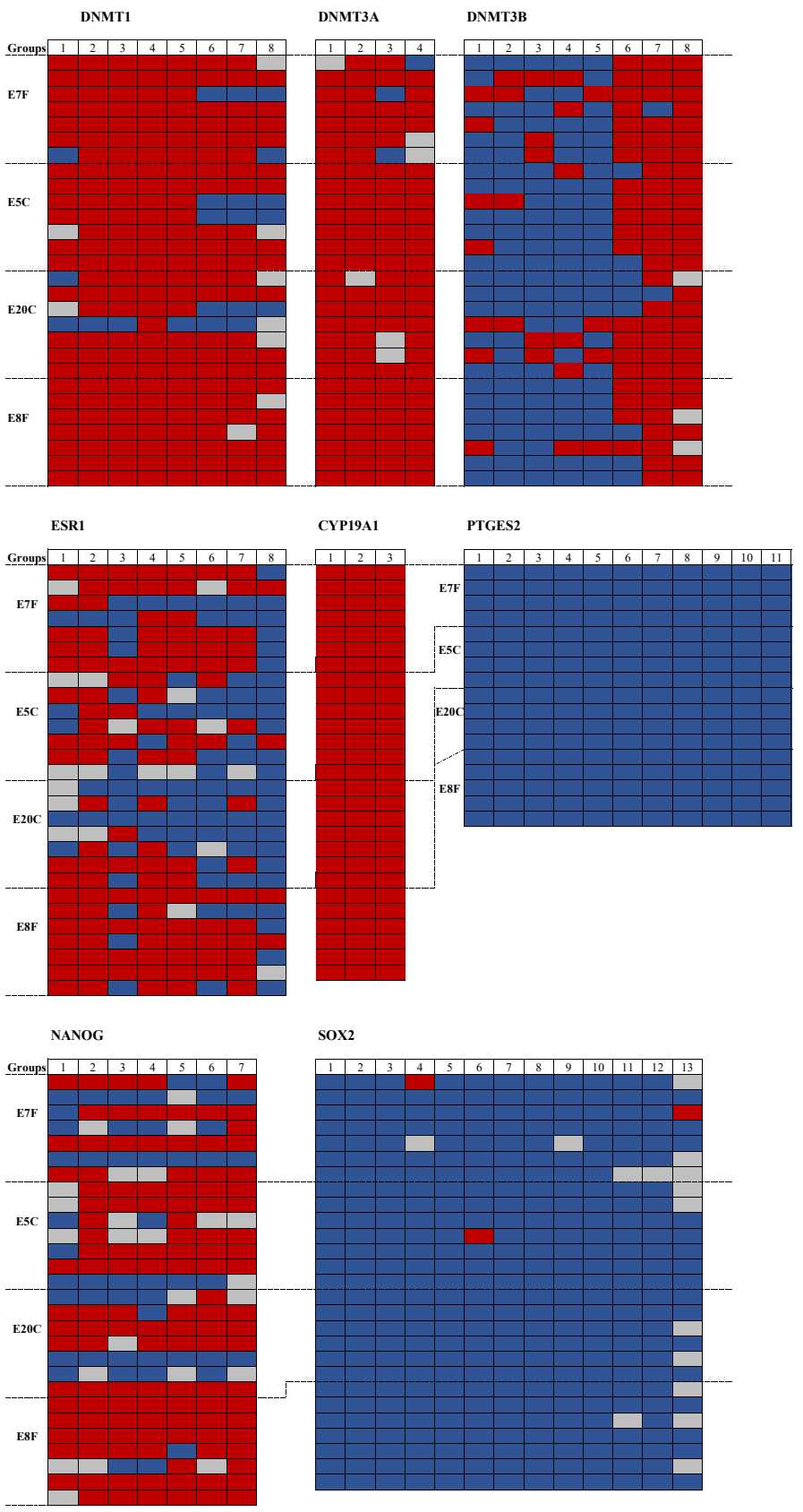

Figure 4. Overview of DNA methylation results of single CpGs for the selected genes. DNA methylation (DNMT1, DNMT3A, DNMT3B), embryo-maternal recognition (ESR1, CYP19A1, PTGES2), and growth and development (NANOG, SOX2) of the equine embryo. Blue box, unmethylated CpG; red box, methylated CpG; gray box, unclear methylation state. One row refers to one embryo and the number of columns refers to the number of CpGs sequenced in the CG-rich region (methprimer CpG island finder) upstream of the gene (Table 2). 
Table 4. Percentage of methylation in the CpG islands of the specific genes ${ }^{\dagger}$.

\begin{tabular}{|c|c|c|c|c|c|c|}
\hline Function & Gene & E7F & E5C & E20C & E8F & $p$-Value \\
\hline Growth \& & SOX2 & 2.2 & 1.1 & 0.0 & 0.0 & 0.62 \\
\hline Development & NANOG & $46.9^{a}$ & $63.3^{a, b}$ & $53.1^{\mathrm{a}}$ & $85.7^{\mathrm{b}}$ & $<0.0001$ \\
\hline \multirow{3}{*}{$\begin{array}{l}\text { Embryo-maternal } \\
\text { communication }\end{array}$} & ESR1 & $64.3^{a, b}$ & $39.3^{b, c}$ & $28.6^{c}$ & $78.6^{\mathrm{a}}$ & $<0.0001$ \\
\hline & CYP19A1 & 100.0 & 100.0 & 100.0 & 100.0 & NS \\
\hline & PTGES2 & 0.0 & 0.0 & 0.0 & 0.0 & NS \\
\hline \multirow{3}{*}{ Methylation } & DNMT1 & $89.3^{a, b}$ & $85.7^{\mathrm{a}, \mathrm{b}}$ & $75.0^{b}$ & $96.4^{\mathrm{a}}$ & 0.009 \\
\hline & DNMT3a & $78.6^{a}$ & $100.0^{b}$ & $89.3^{a, b}$ & $100.0^{b}$ & 0.006 \\
\hline & DNMT3b & 53.6 & 30.4 & 44.6 & 33.9 & 0.052 \\
\hline
\end{tabular}

${ }^{\dagger}$ Specific genes related to growth \& development, embryo-maternal recognition, and methylation functions in fresh control (E7F and E8F) and stored embryos (E5C and E20C); embryos day seven fresh, E7F; stored at $5{ }^{\circ} \mathrm{C}, \mathrm{E} 5 \mathrm{C}$, and $20^{\circ} \mathrm{C}, \mathrm{E} 20 \mathrm{C}$; fresh embryos day eight, E8F. $a, b, c$ Differences among groups within genes are indicated by superscript letters and are highlighted in gray $(p<0.05)$.

\subsection{Global methylation-5hmC and $5 \mathrm{mC}$}

The fluorescence intensity ( 255 to $4.97 \times 10^{6} \mathrm{au}$ ) varied among embryos. The global methylation was, however, not affected by treatment, irrespective of the antibody $(5 \mathrm{mC}$ or $5 \mathrm{hmC}$; Figure 5). When immune expression was compared between antibodies within each treatment, E7F had a greater $(p<0.05)$ expression of $5 \mathrm{hmC}$ compared to $5 \mathrm{mC}$. Among all other groups, expression did not differ between $5 \mathrm{hmC}$ compared to $5 \mathrm{mC}$.

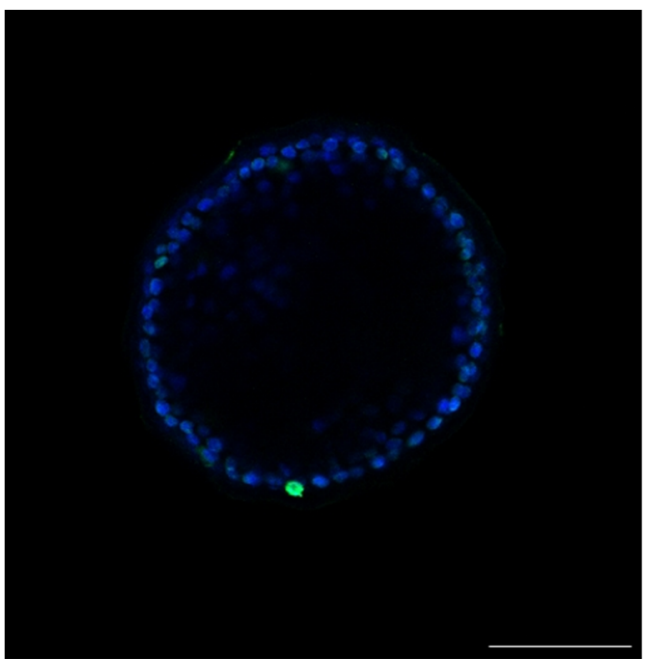

$5 \mathrm{mc}$

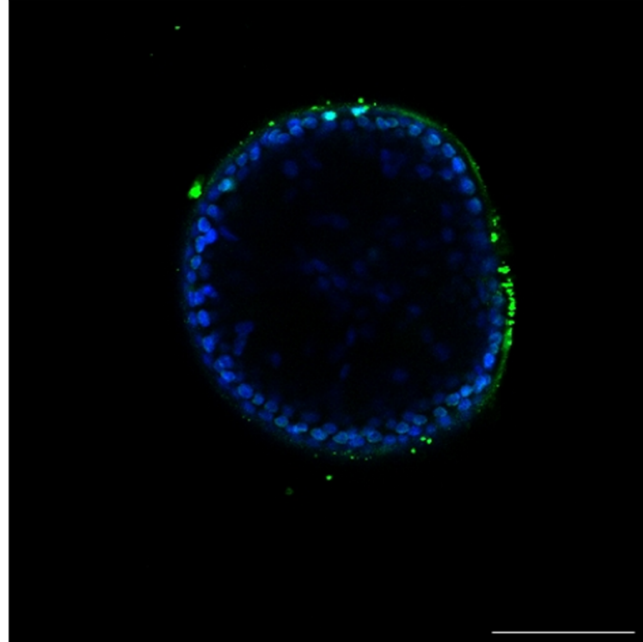

$5 \mathrm{hmc}$

Figure 5. Illustrative image of $5 \mathrm{mC}$ and $5 \mathrm{hmC}$ immunolabeling in equine stored embryo at $20{ }^{\circ} \mathrm{C}$ after $24 \mathrm{~h}$. Equine embryos had similar $5 \mathrm{mC}$ and $5 \mathrm{hmC}$ immunolabeling among treatments. Green labeling represents methylated stained cells. Blue labeled cells are stained with DAPI to allow the identification of the embryonic cells and permit the quantification of global methylation. Scale bar, $100 \mu \mathrm{m}$

\section{Discussion}

To the best of our knowledge, the present study is the first to analyze the effects of storage temperature $\left(5\right.$ and $\left.20^{\circ} \mathrm{C}\right)$ on development, relative mRNA abundance and DNA methylation in equine embryos processed for shipment using a commercial holding medium. Untreated fresh embryos collected on day seven and day eight were included as controls to determine changes in relative mRNA abundance and DNA methylation associated with embryo age itself. Whereas difference in size of embryos collected on days seven and eight after ovulation, as well as a considerable variance in size of embryos collected on the same day, is not surprising and in agreement with previous studies [45-47] In this context, it has to be considered that in this study ovulation was assessed at $24 \mathrm{~h}$-intervals, 
which has most likely contributed to the variation in size within the embryos collected on days seven and eight after ovulation. Nevertheless, effects of storage temperature on equine embryo size have not yet been reported. Interestingly, embryonic size was slightly, but significantly, smaller in embryos stored at $20^{\circ} \mathrm{C}$, whereas embryos stored at $5{ }^{\circ} \mathrm{C}$ were larger after $24 \mathrm{~h}$. It has been reported previously that the rapid increase in size of equine embryos starting on day seven mainly depends on influx of fluid into the blastocoel allowed by the formation of an osmotic gradient due to activity of $\alpha 1 / \beta 1 \mathrm{Na}+/ \mathrm{K}+$-ATPase (reviewed by [47]). This enzyme has been detected in horse embryos not earlier than day eight after ovulation [48]. The present results suggest that storage at $20^{\circ} \mathrm{C}$ may inhibit the activity of this enzyme but, in comparison to in vivo-produced embryos, decreased enzyme activity is also present in embryos stored at $5^{\circ} \mathrm{C}$. Interestingly, in all embryos analyzed for gene expression in the present study, ATP1A1, the gene encoding for the $\alpha 1$ subunit of the $\mathrm{Na}+/ \mathrm{K}+$-ATPase was detected but there were no differences in relative mRNA abundance among groups. The mRNA abundance is, however, not necessarily associated with enzyme activity. In day eight embryos, immunohistochemistry of $\mathrm{Na}+/ \mathrm{K}+-\mathrm{ATP}$ ase revealed a pronounced protein expression of this enzyme in the whole trophoblast [49]. This suggests that the technique would not allow detection of differences among groups in the present investigation. We did not detect changes in $\mathrm{pH}$ and oxidative balance of the holding medium during storage irrespective of temperature. However, in approximately $25 \%$ of the embryos a partial separation of the trophoblast from the zona pellucida occurred. This finding is in accordance with a previous description of morphological abnormalities after 12 or $24 \mathrm{~h}$ of cooled storage in equine embryos [32] and may also be associated with delayed formation of an osmotic gradient due to impaired activity of $\alpha 1 / \beta 1 \mathrm{Na}+/ \mathrm{K}+$-ATPase and subsequent collapse of the blastocoel. Among the genes we assessed in this study, SOX2, NANOG and $D N M T 3 B$ are associated with pluripotency, and have been detected in equine pluripotent cells and in equine MSCs [50]. Interestingly, relative mRNA abundance of these genes had a positive correlation among each other in our study; the interaction among SOX2 and NANOG is necessary to regulate embryonic stem cell self-renewal [51]. Notwithstanding, the relative mRNA abundance of SOX2, NANOG and DNMT3B was affected by storage temperature in a way that it was similar in day seven control embryos and embryos stored at $5{ }^{\circ} \mathrm{C}$ on the one hand, and day eight controls and embryos stored at $20^{\circ} \mathrm{C}$ on the other hand. Changes in PTGES2 and DNMT1 relative mRNA abundance followed the same pattern. Moreover, correlation analysis demonstrated that POU5F1 and CYP19A1 have an opposed interaction at this embryo stage. This suggests that storage of equine day seven embryos at $20^{\circ} \mathrm{C}$ does not prevent changes in relative mRNA abundance that also occur between day seven and day eight in embryos in utero. Consequently, a storage temperature of $20^{\circ} \mathrm{C}$ may be beneficial for embryo development when compared to a storage temperature of $5{ }^{\circ} \mathrm{C}$ where gene expression of the respective candidate genes stayed at the same level as in the control embryos collected on day seven. The relative mRNA abundance of other candidate genes, namely IGF1, a gene associated with embryonic development because it increases cell proliferation and decreases cell apoptosis [52,53], CYP19A1, the gene encoding aromatase, and the proapoptotic gene $B A X$, was similar among stored embryos irrespective of temperature, as well as in control embryos collected on day seven, but differed in embryos collected on day eight. This suggests that embryo storage at $20^{\circ} \mathrm{C}$ may have beneficial effects in comparison to $5{ }^{\circ} \mathrm{C}$ regarding the expression of some, but not all, genes. These findings are in agreement with higher pregnancy rates after transfer of shipped equine embryos with an arrival temperature between 10 and $16{ }^{\circ} \mathrm{C}$ in comparison to embryos transported in cooler conditions [54].

Methylation of DNA occurs during the migration of proliferating primordial germ cells but demethylation in postmigratory germ cells. A second wave of DNA demethylation takes place in cleavage stage embryos, with DNA methylation being minimal at the blastocyst stage ([55]; recently reviewed by [56]). In the present study, only minor differences in the methylation status of candidate genes were detected between fresh embryos collected on day seven and day eight, and the two groups of stored embryos. An interesting finding 
was hypermethylation of NANOG in embryos collected on day eight in comparison to the other groups, demonstrating that NANOG methylation reprogramming is highly active between days seven and eight of equine embryonic development. A hypomethylation of $D N M T 3 a$ in fresh day-seven embryos in comparison to all the other groups where embryo age was eight days, is most probably only age-related. Changes in the methylation status of genes that regulate embryo development have been described in porcine blastocysts during in vitro culture and were suggested to contribute to early pregnancy loss [57]. In the present study, either demethylation or a delay in methylation of CpG islands of specific genes could be a consequence of maintaining transcriptional activation [58] at the temperatures used during storage compared to physiological temperatures. The embryo environment associated with ART had long-lasting consequences in mouse, ruminant and human embryos [59-61]. A major setback associated with the introduction of in vitro production of ruminant embryos was the occurrence of large offspring syndrome [59]. This condition has caused considerable loss after transfer of in vitro produced ruminant embryos and has been linked to the use of serum in the culture media [59] altering gene expression and DNA methylation [14]. Comparable problems, however, have not yet been described in foals derived by ART, which is in agreement with the findings of the present study with only minor changes of methylation status of the candidate genes.

\section{Conclusions}

Our study investigated for the first time the relative mRNA abundance of some candidate genes, as well as the global and gene-specific DNA methylation status in fresh equine embryos collected on days seven and eight after ovulation. Moreover, we demonstrate that short-term storage of embryos alters the expression of genes involved in embryo development and methylation. Results suggest some beneficial effects of storage at $20^{\circ} \mathrm{C}$ in comparison to $5^{\circ} \mathrm{C}$. However, further studies to clarify impacts after embryo transfer on implantation, embryo development and pregnancy success will benefit the future of ARTs in equine industry.

Author Contributions: Conceptualization: G.D.A.G.; D.S.; C.A. Data curation: G.D.A.G.; R.E.; C.A. Investigation and methodology: G.D.A.G.; M.M.; D.S.; R.E.; C.A. Writing: G.D.A.G.; C.A. Writingreview \& editing: G.D.A.G.; D.S.; M.M.; R.E.; CA. All authors have read and agreed to the published version of the manuscript.

Funding: This work was supported by University of Veterinary Medicine Vienna, Austria.

Institutional Review Board Statement: The study was conducted according to the guidelines of the Declaration of Helsinki, and approved by the by the institutional ethics committee (Veterinary University Vienna) and the Austrian Ministry for Education, Science and Research (license number BMWFW-68.205/0135-WF/V/3b/2014).

Data Availability Statement: The data analyzed during the current study are available from the corresponding authors on reasonable request.

Acknowledgments: The authors thank the VetCore Facility (Imaging) of the University of Veterinary Medicine Vienna for their support and resources.

Conflicts of Interest: The authors declare no conflict of interest.

\footnotetext{
Abbreviations

ART: assisted reproduction techniques; BWS: Beckwith-Wiedemann syndrome; CpG: cytosineguanine dinucleotides; DNMTs: DNA methyltransferases; MDA: malondialdehyde; PBS: phosphatebuffered saline; PCR: polymerase chain reaction.
} 


\section{References}

1. Squires, E. Current reproductive technologies impacting equine embryo production. J. Equine Vet. Sci. 2020, 89, 102981. [CrossRef] [PubMed]

2. Hinrichs, K.; Choi, Y.-H. Equine embryo biopsy, genetic testing, and cryopreservation. J. Equine Vet. Sci. 2012, 32, 390-396. [CrossRef]

3. Foss, R.; Ortis, H.; Hinrichs, K. Effect of potential oocyte transport protocols on blastocyst rates after intracytoplasmic sperm injection in the horse. Equine Vet. J. 2013, 45, 39-43. [CrossRef] [PubMed]

4. Squires, E.L.; Carnevale, E.M.; McCue, P.M.; Bruemmer, J.E. Embryo technologies in the horse. Theriogenology 2003, 59, 151-170. [CrossRef]

5. Watson, A.J.; Westhusin, M.E.; de Sousa, P.A.; Betts, D.H.; Barcroft, L.C. Gene expression regulating blastocyst formation. Theriogenology 1999, 51, 117-133. [CrossRef]

6. Rader, K.; Choi, Y.-H.; Hinrichs, K. Intracytoplasmic sperm injection, embryo culture, and transfer of in vitro-produced blastocysts. Vet. Clin. Equine Pract. 2016, 32, 401-413. [CrossRef]

7. O'Neill, C. The epigenetics of embryo development. Anim. Front. 2015, 5, 42-49. [CrossRef]

8. Bird, A. DNA methylation patterns and epigenetic memory. Genes Dev. 2002, 16, 6-21. [CrossRef]

9. Jaenisch, R.; Bird, A. Epigenetic regulation of gene expression: How the genome integrates intrinsic and environmental signals. Nat. Genet. 2003, 33, 245-254. [CrossRef]

10. Reik, W.; Dean, W.; Walter, J. Epigenetic reprogramming in mammalian development. Science 2001, 293, 1089-1093. [CrossRef]

11. Vrooman, L.A.; Rhon-Calderon, E.A.; Chao, O.Y.; Nguyen, D.K.; Narapareddy, L.; Dahiya, A.K.; Putt, M.E.; Schultz, R.M.; Bartolomei, M.S. Assisted reproductive technologies induce temporally specific placental defects and the preeclampsia risk marker sFLT1 in mouse. Development 2020, 147. [CrossRef]

12. Schieve, L.A.; Cohen, B.; Nannini, A.; Ferre, C.; Reynolds, M.A.; Zhang, Z.; Jeng, G.; Macaluso, M.; Wright, V.C. A populationbased study of maternal and perinatal outcomes associated with assisted reproductive technology in Massachusetts. Matern. Child Health J. 2007, 11. [CrossRef] [PubMed]

13. Jacob, S.; Moley, K.H. Gametes and embryo epigenetic reprogramming affect developmental outcome: Implication for assisted reproductive technologies. Pediatr. Res. 2005, 58, 437-446. [CrossRef] [PubMed]

14. Chen, Z.; Robbins, K.M.; Wells, K.D.; Rivera, R.M. Large offspring syndrome: A bovine model for the human loss-of-imprinting overgrowth syndrome Beckwith-Wiedemann. Epigenetics 2013, 8, 591-601. [CrossRef]

15. Leese, H.J. Metabolism of the preimplantation embryo: 40 years on. Reproduction 2012, 143, 417-427. [CrossRef] [PubMed]

16. McCaw, B.A.; Stevenson, T.J.; Lancaster, L.T. Epigenetic responses to temperature and climate. Integr. Comp. Biol. 2020, 60, 1469-1480. [CrossRef]

17. Canovas, S.; Ivanova, E.; Romar, R.; García-Martínez, S.; Soriano-Ubeda, C.; García-Vázquez, F.A.; Saadeh, H.; Andrews, S.; Kelsey, G.; Coy, P. DNA methylation and gene expression changes derived from assisted reproductive technologies can be decreased by reproductive fluids. Elife 2017, 6, e23670. [CrossRef] [PubMed]

18. Canovas, S.; Ross, P.J.; Kelsey, G.; Coy, P. DNA methylation in embryo development: Epigenetic impact of ART (assisted reproductive technologies). Bioessays 2017, 39, 1700106. [CrossRef]

19. Bonometti, S.; Menarim, B.C.; Reinholt, B.M.; Ealy, A.D.; Johnson, S.E. Growth factor modulation of equine trophoblast mitosis and prostaglandin gene expression. J. Anim. Sci. 2019, 97, 865-873. [CrossRef] [PubMed]

20. Breton-Larrivée, M.; Elder, E.; McGraw, S. DNA methylation, environmental exposures and early embryo development. Anim. Reprod. 2019, 16, 465-474. [CrossRef] [PubMed]

21. Okano, M.; Bell, D.W.; Haber, D.A.; Li, E. DNA methyltransferases Dnmt3a and Dnmt3b are essential for de novo methylation and mammalian development. Cell 1999, 99, 247-257. [CrossRef]

22. Li, E. Chromatin modification and epigenetic reprogramming in mammalian development. Nat. Rev. Genet. 2002, 3, 662-673. [CrossRef] [PubMed]

23. Suetake, I.; Shinozaki, F.; Miyagawa, J.; Takeshima, H.; Tajima, S. DNMT3L stimulates the DNA methylation activity of Dnmt3a and Dnmt3b through a direct interaction. J. Biol. Chem. 2004, 279, 27816-27823. [CrossRef] [PubMed]

24. Okamoto, Y.; Yoshida, N.; Suzuki, T.; Shimozawa, N.; Asami, M.; Matsuda, T.; Kojima, N.; Perry, A.C.F.; Takada, T. DNA methylation dynamics in mouse preimplantation embryos revealed by mass spectrometry. Sci. Rep. 2016, 6, 1-9. [CrossRef]

25. Lucas, E. Epigenetic effects on the embryo as a result of periconceptional environment and assisted reproduction technology. Reprod. Biomed. Online 2013, 27, 477-485. [CrossRef] [PubMed]

26. Thompson, J.G.; Lane, M.; Gilchrist, R.B. Metabolism of the bovine cumulus-oocyte complex and influence on subsequent developmental competence. Soc. Reprod. Fertil. Suppl. 2007, 64, 179. [CrossRef] [PubMed]

27. Urrego, R.; Rodriguez-Osorio, N.; Niemann, H. Epigenetic disorders and altered gene expression after use of assisted reproductive technologies in domestic cattle. Epigenetics 2014, 9, 803-815. [CrossRef] [PubMed]

28. Poirier, M.; Smith, O.E.; Therrien, J.; Rigoglio, N.N.; Miglino, M.A.; Silva, L.A.; Meirelles, F.V.; Smith, L.C. Resiliency of equid H19 imprint to somatic cell reprogramming by oocyte nuclear transfer and genetically induced pluripotency. Biol. Reprod. 2020, 102, 211-219. [CrossRef]

29. Grant, D.M.; Macedo, A.; Toms, D.; Klein, C. Fibrinogen in equine pregnancy as a mediator of cell adhesion, an epigenetic and functional investigation. Biol. Reprod. 2020, 102, 170-184. [CrossRef] 
30. Aurich, C. Reproductive cycles of horses. Anim. Reprod. Sci. 2011, 124, 220-228. [CrossRef]

31. Aurich, J.E.; Schönherr, U.; Hoppe, H.; Aurich, C. Effects of antioxidants on motility and membrane integrity of chilled-stored stallion semen. Theriogenology 1997, 48, 185-192. [CrossRef]

32. McKinnon, A.O.; Squires, E.L. Equine embryo transfer. Vet. Clin. North Am. Equine Pract. 1988, 4, 305-333. [CrossRef]

33. Ayala, A.; Muñoz, M.F.; Argüelles, S. Lipid peroxidation: Production, metabolism, and signaling mechanisms of malondialdehyde and 4-hydroxy-2-nonenal. Oxid. Med. Cell. Longev. 2014, 2014. [CrossRef] [PubMed]

34. Beckelmann, J.; Budik, S.; Helmreich, M.; Palm, F.; Walter, I.; Aurich, C. Sex-dependent insulin like growth factor-1 expression in preattachment equine embryos. Theriogenology 2013, 79, 193-199. [CrossRef] [PubMed]

35. Hackett, C.H.; Greve, L.; Novakofski, K.D.; Fortier, L.A. Comparison of gene-specific DNA methylation patterns in equine induced pluripotent stem cell lines with cells derived from equine adult and fetal tissues. Stem Cells Dev. 2012, 21, 1803-1811. [CrossRef] [PubMed]

36. Köhne, M.; Ille, N.; Erber, R.; Razavi, M.S.A.; Walter, I.; Aurich, C. Effects of periovulatory gonadotrophin treatment on luteal function and endometrial expression of selected genes in cyclic pony mares. Theriogenology 2016, 86, 2147-2155. [CrossRef] [PubMed]

37. Scarlet, D.; Ille, N.; Ertl, R.; Alves, B.G.; Gastal, G.D.A.; Paiva, S.O.; Gastal, M.O.; Gastal, E.L.; Aurich, C. Glucocorticoid metabolism in equine follicles and oocytes. Domest. Anim. Endocrinol. 2017, 59, 11-22. [CrossRef]

38. Scarlet, D.; Ertl, R.; Aurich, C.; Steinborn, R. The orthology clause in the next generation sequencing era: Novel reference genes identified by RNA-seq in humans improve normalization of neonatal equine ovary RT-qPCR data. PLoS ONE 2015, 10, e0142122. [CrossRef] [PubMed]

39. Kenkel, C.D.; Aglyamova, G.; Alamaru, A.; Bhagooli, R.; Capper, R.; Cunning, R.; deVillers, A.; Haslun, J.A.; Hédouin, L.; Keshavmurthy, S. Development of gene expression markers of acute heat-light stress in reef-building corals of the genus Porites. PLoS ONE 2011, 6, e26914. [CrossRef]

40. Livak, K.J.; Schmittgen, T.D. Analysis of relative gene expression data using real-time quantitative PCR and the $2-\Delta \Delta C T$ method. Methods 2001, 25, 402-408. [CrossRef] [PubMed]

41. Heinzmann, J.; Mattern, F.; Aldag, P.; Bernal-Ulloa, S.M.; Schneider, T.; Haaf, T.; Niemann, H. Extended in vitro maturation affects gene expression and DNA methylation in bovine oocytes. Mhr Basic Sci. Reprod. Med. 2015, 21, 770-782. [CrossRef] [PubMed]

42. Li, L.-C.; Dahiya, R. MethPrimer: Designing primers for methylation PCRs. Bioinformatics 2002, 18, 1427-1431. [CrossRef] [PubMed]

43. Santos, F.; Dean, W. Using immunofluorescence to observe methylation changes in mammalian preimplantation embryos. In Nuclear Reprogramming; Springer: Berlin/Heidelberg, Germany, 2006; pp. 129-138.

44. Heras, S.; Smits, K.; de Schauwer, C.; van Soom, A. Dynamics of 5-methylcytosine and 5-hydroxymethylcytosine during pronuclear development in equine zygotes produced by ICSI. Epigenetics Chromatin 2017, 10, 1-13. [CrossRef] [PubMed]

45. Colchen, S.; Battut, I.; Fiéni, F.; Tainturier, D.; Siliart, B.; Bruyas, J.F. Quantitative histological analysis of equine embryos at exactly 156 and $168 \mathrm{~h}$ after ovulation. J. Reprod. Fertil. Suppl. 2000, 56, 527-537.

46. Panzani, D.; Rota, A.; Marmorini, P.; Vannozzi, I.; Camillo, F. Retrospective study of factors affecting multiple ovulations, embryo recovery, quality, and diameter in a commercial equine embryo transfer program. Theriogenology 2014, 82, 807-814. [CrossRef] [PubMed]

47. Aurich, C.; Budik, S. Early pregnancy in the horse revisited-does exception prove the rule? J. Anim. Sci. Biotechnol. 2015, 6, 1-8. [CrossRef]

48. Waelchli, R.O.; MacPhee, D.J.; Kidder, G.M.; Betteridge, K.J. Evidence for the presence of sodium- and potassium-dependent adenosine triphosphatase $\alpha 1$ and $\beta 1$ subunit isoforms and their probable role in blastocyst expansion in the preattachment horse conceptus. Biol. Reprod. 1997, 57, 630-640. [CrossRef]

49. Budik, S.; Walter, I.; Tschulenk, W.; Helmreich, M.; Deichsel, K.; Pittner, F.; Aurich, C. Significance of aquaporins and sodium potassium ATPase subunits for expansion of the early equine conceptus. Reproduction 2008, 135, 497-508. [CrossRef]

50. Esteves, C.L.; Sharma, R.; Dawson, L.; Taylor, S.E.; Pearson, G.; Keen, J.A.; McDonald, K.; Aurich, C.; Donadeu, F.X. Expression of putative markers of pluripotency in equine embryonic and adult tissues. Vet. J. 2014, 202, 533-535. [CrossRef]

51. Gagliardi, A.; Mullin, N.P.; Ying Tan, Z.; Colby, D.; Kousa, A.I.; Halbritter, F.; Weiss, J.T.; Felker, A.; Bezstarosti, K.; Favaro, R.; et al. A direct physical interaction between Nanog and Sox2 regulates embryonic stem cell self-renewal. EMBO J. 2013, 32. [CrossRef]

52. Herrler, A.; Krusche, C.A.; Beier, H.M. Insulin and insulin-like growth factor-I promote rabbit blastocyst development and prevent apoptosis. Biol. Reprod. 1998, 59, 1302-1310. [CrossRef]

53. Wang, L.M.; Feng, H.L.; Ma, Y.Z.; Cang, M.; Li, H.J.; Yan, Z.; Zhou, P.; Wen, J.X.; Bou, S.; Liu, D.J. Expression of IGF receptors and its ligands in bovine oocytes and preimplantation embryos. Anim. Reprod. Sci. 2009, 114, 99-108. [CrossRef] [PubMed]

54. Alonso, C.; Bragulat, A.F.; Llorente, J.; Morikawa, I.; von Meyeren, M.; Losinno, L. Pregnancy rates for cooled transported equine embryos according to size and arrival temperature. J. Equine Vet. Sci. 2020, 89, 103078. [CrossRef]

55. Monk, M.; Boubelik, M.; Lehnert, S. Temporal and regional changes in DNA methylation in the embryonic, extraembryonic and germ cell lineages during mouse embryo development. Development 1987, 99, 371-382. [CrossRef]

56. Edwards, J.R.; Yarychkivska, O.; Boulard, M.; Bestor, T.H. DNA methylation and DNA methyltransferases. Epigenetics Chromatin 2017, 10, 1-10. [CrossRef] [PubMed] 
57. Marinho, L.S.R.; Rissi, V.B.; Lindquist, A.G.; Seneda, M.M.; Bordignon, V. Acetylation and methylation profiles of H3K27 in porcine embryos cultured in vitro. Zygote 2017, 25, 575-582. [CrossRef]

58. Bestor, T.H.; Edwards, J.R.; Boulard, M. Notes on the role of dynamic DNA methylation in mammalian development. Proc. Natl. Acad. Sci. USA 2015, 112, 6796-6799. [CrossRef] [PubMed]

59. Young, L.E.; Sinclair, K.D.; Wilmut, I. Large offspring syndrome in cattle and sheep. Rev. Reprod. 1998, 3, 155-163. [CrossRef] [PubMed]

60. Kleijkers, S.H.M.; van Montfoort, A.P.A.; Smits, L.J.M.; Viechtbauer, W.; Roseboom, T.J.; Nelissen, E.C.M.; Coonen, E.; Derhaag, J.G.; Bastings, L.; Schreurs, I.E.L.; et al. IVF culture medium affects post-natal weight in humans during the first 2 years of life. Hum. Reprod. 2014, 29, 661-669. [CrossRef] [PubMed]

61. Fernández-Gonzalez, R.; Moreira, P.; Bilbao, A.; Jiménez, A.; Pérez-Crespo, M.; Ramírez, M.A.; de Fonseca, F.R.; Pintado, B.; Gutiérrez-Adán, A. Long-term effect of in vitro culture of mouse embryos with serum on mRNA expression of imprinting genes, development, and behavior. Proc. Natl. Acad. Sci. USA 2004, 101, 5880-5885. [CrossRef] 